\title{
ANALISIS JUAL BELI HAK CIPTA DALAM PERSPEKTIF HUKUM PIDANA ISLAM DAN UNDANG-UNDANG NOMOR 28 TAHUN 2014
}

\author{
Oleh: \\ Ghurrotul Muhajjalah ${ }^{1}$ \\ Email: kafa.khanza34@gmail.com \\ Nasiri ${ }^{2}$ \\ Email: nasiri.abadi@yahoo.co.id
}

\begin{abstract}
This study aims to seek legal certainty from the practice of buying and selling copyright that occurs in society. By emphasizing the study of the point of view of Islamic criminal law in answering the legality of the practice of buying and selling copyright logically and comprehensively. Next, do a deeper analysis and study of the ratio legislation of Law No. 28 of 2014 concerning Copyright. The design of this study is normative legal research with a statute approach and comparative approach. Data collection techniques used documentation in the form of library studies with sources of legal material. The results of this study indicate that: 1) copyright is a new term that is still unfamiliar in the context of Islamic criminal law. Although its application has been indirectly recognized since the time of the Prophet with the necessity to include the name of the author in each of the writings cited. This is true on the basis of copyright ownership of property ownership. So that related to the legality of copyright sale and purchase transactions are answered on the basis of the legality of buying and selling in general. The difference is that the object (mauqud aih alaih) of copyright sale and purchase is based on the perspective of $f$ urf contained in the criteria of the benefits of goods (muntafa'bih) which are maqsu and 'urfan or in other words the public has economic value and is worth trading. 2) Copyright sale and purchase transactions are transactions that have been legalized for a long time in positive law in Indonesia. This is based on the existence of related rights in the exclusive rights inherent in a creator. The related rights are in the form of economic and moral rights. In the end, these economic rights are the basis of the legality and royalties generated from copyright sale and purchase transactions based on the legality of other transactions listed in Article 9 paragraph (1) of Law No. 28 of 2014 concerning copyright.
\end{abstract}

Key words: copyright, buying and selling, Islamic Criminal Law Surabaya.

${ }^{1}$ Mahasiswa Pascasarjana Prodi Ilmu Qurán dan Tafsir Universitas Islam Negeri

${ }^{2}$ Dosen STAI Taruna Surabaya 


\section{Pendahuluan}

Akal merupakan salah satu anugrah yang diberikan Allah terhadap manusia. Anugrah inilah yang kemudian menjadikan manusia dipandang lebih sempurna dari makhluk ciptaan Allah lainnya. Akal merupakan salah satu dari tiga unsur penting yang terdapat pada diri manusia selain hati dan raga. $^{3}$ Tiga unsur tersebut merupakan satu kesatuan dalam membentuk diri manusia. Dari ketiga unsur tersebut, yang paling istimewa yang dimiliki manusia yaitu kemampuannya untuk menalar. Kemampuan menalar hanya dimiliki oleh manusia dan sebaliknya tidak dimiliki oleh makhluk selain manusia. Karena dengannya manusia mampu berfikir, membedakan hal-hal yang baik dan buruk serta mampu berinovasi dengan menciptakan hal-hal dan kebudayaan-kebudayaan baru yang pada akhirnya menjadikan kehidupannya lebih mudah.

Dengan kemampuan yang terdapat pada akal, Islam memerintahkan manusia untuk mengamati fenomena dan pertumbuhan alam sehingga pada akhirnya bisa memahami kebenaran dari Allah. Dengan kata lain akal akan berfungsi atau bekerja dengan semestinya jika digunakan dengan optimal. Terdapat banyak ayat dalam Al Qur'an yang menegaskan tentang fungsi akal, di antaranya adalah yang disebutkan dalam surah 30/Ar Rum: 24:

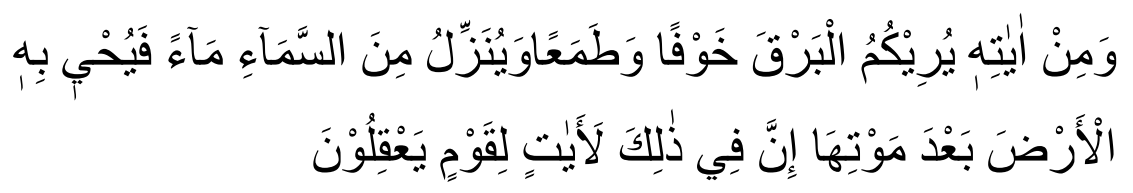

"Dan di antara tanda-tanda kekuasaan-Nya, Dia memperlihatkan kepadamu kilat untuk menimbulkan ketakutan, harapan, dan Dia menurunkan air hujan dari langit, lalu menghidupkan bumi dengan

${ }^{3}$ Agus Suryana. Al Mashlahah Jurnal Hukum Dan Pranata Sosial Islam Hak Cipta Perspektif Hukum Islam. Hlm 247. 
air itu sesudah matinya. Sesungguhnya pada yang demikian itu terdapat tanda-tanda bagi kaum yang menggunakan akalnya."4

Ayat tersebut memang tidak menyebutkan secara implisit fungsi akal, akan tetapi melalui isi kandungannya Allah menyebutkan bahwa hanya kaum yang menggunakan akalnya saja yang mampu memperhatikan keadaan-keadaan tersebut. Selain memperhatikan keadaan sekelilingnya, akal juga berfungsi menciptkan inovasi, gagasan serta ide. Ketiga hal tersebut lahir dari kerja keras akal untuk membuka pengetahuan baru untuk kemudian dituangkan dalam sebuah media agar orang lain bisa memanfaatkannya. Dalam ruang lingkup Hak Kekayaan Intelektual (HAKI) hasil dari kerja akal tersebut melahirkan suatu hak yang disebut dengan hak cipta.

Definisi hak cipta secara yuridis dijelaskan dalam Undang-Undang No. 28 Tahun 2014 tentang Hak Cipta, disebutkan bahwa hak cipta adalah hak eksklusif bagi pencipta atau penerima hak untuk mengumumkan atau memperbanyak ciptaannya atau memberikan izin untuk itu dengan tidak mengurangi pembatasan-pembatasan menurut peraturan perundangundangan yang berlaku. ${ }^{5}$ Hak eksklusif tersebut menjadikan ciptaan ini menjadi hak yang semata-mata diperuntukkan bagi pencipta atau pihak lain yang diperbolehkan memanfaatkan hak tersebut dengan seizin pencipta. ${ }^{6}$

Hak cipta dalam khazanah fikih Islam kontemporer dikenal dengan istilah haq al-ibtikar, pengertian keduanya adalah kewenangan atau kepemilikan atas suatu karya cipta yang baru diciptakan. ${ }^{7}$ Dalam tinjauan hukum hak cipta dalam Islam, status hak yang muncul kemudian

${ }^{4}$ Departemen Agama RI. Al Qur'an dan Terjemahannya. Jakarta: Surya Cipta Aksara. 1993, hlm 644.

${ }^{5}$ Undang-Undang Nomor 28 Tahun 2014 tentang Hak Cipta

${ }^{6}$ Tim Lindsey dkk. Hak Kekayaan Intelektual, Suatu Pengantar. Bandung: Alumni. 2011, hlm 6.

${ }^{7}$ Rochim Al Audah. Al Mashlahah Jurnal Hukum Dan Pranata Sosial Islam: Hak Cipta dan Perlindungan Hak Kekayaan Intelektual dalam Perspektif Hukum Islam dan Perundang-undangan. hlm 576. 
disandarkan kepada hak milik (haqq al milkiyah8). Sedangkan perlindungan terhadap hak kepemilikan merupakan salah satu dari tujuan syariat Islam (maqasid as-syari'ah), hal ini termasuk kebutuhan primer bagi setiap pencipta atas karya ciptanya. Oleh sebab itulah maka kepemilikan tersebut akan dilindungi sebagaimana perlindungan terhadap benda karena Islam mengakui hak cipta sebagai salah satu kepemilikan harta.

Dari beberapa teori terkait konsep hak cipta tersebut dalam penempatannya terhadap dinamika modernisasi memerlukan kajian ulang secara intensif. Sebab darinya terlahir produk-produk transaksi baru yang memerlukan jawaban secara komprehensif baik dari perspektif hukum pidana Islam dan hukum positif di Indonesia. Terbukti baru-baru ini Indonesia International Book Fair (IIBF) 2016 sukses menggelar bisnis jual beli hak cipta antara penerbit Indonesia dan negara asing. "Kita mulai membangun bisnis penjualan hak cipta dengan mancanegara, mulai tiga tahun terakhir. Alhamdulillah di tahun ini ada peningkatan yang luar biasa." kata Ketua Panitia IIBF 2016, Kuslityarini di JCC Senayan, Jakarta, Jumat (30/9). Ia menjelaskan, peserta jual beli hak cipta hampir 80 penerbit. Angka tersebut lebih besar dari target IIBF 2016 yang hanya 50 peserta "penjualan hak cipta mulai meningkat, ada peningkatan dari tahun ke tahun di IIBF," tutur Rini. Andi Nur Aminah. ${ }^{9}$

Keberadaan transaksi jual beli hak cipta tersebut tentunya menimbulkan pertanyaan besar bagi masyarakat Indonesia yang mayoritas penduduknya memeluk agama Islam. Mengingat dalam hukum Islam, hak cipta pun masih menjadi konsep hak yang terbilang baru. Oleh karenanya, selanjutnya bagaimana legalitas transaksi jual beli hak cipta itu mampu menjawab segala pertanyaan yang timbul dari masyarakat sebagai reaksi dari sikap hati-hati yang dimiliki sebagai pemeluk agama yang taat. Sehingga nantinya transaksi jual beli hak cipta itu benar-benar membawa

\footnotetext{
${ }^{8}$ Hak milik (almilkiyah) adalah hubungan keterikatan antar seseorang dengan harta yang dikukuhkan dan dilegitimasi keabsahannya oleh syara'. Lihat: wahbah Az Zuhaili. Fiqh Islam waAdillatuh jilid 6 hlm 449

${ }^{9}$ Andi Nur Aminah. IIBF 2016 Sukses Gelar Bisnis Jual Beli Hak Cipta.http://m.republika.co.id/berita/nasional/umum/16/10/01/oec8n4384-iibf-2016-suksesgelar-bisnis-jual-beli-hak-cipta. diakses tanggal 26 November 2018.
} 
manfaat serta maslahah bagi seluruh masyarakat dengan didasari status hukum yang jelas.

Penelitian ini bertujuan untuk menganalisis: (1) ketentuan praktik jual beli hak cipta dalam perspektif hukum pidana Islam; (2) ketentuan praktik jual beli hak cipta dalam prspektif Undang-Undang Nomor 28 Tahun 2014 tentang Hak Cipta; (3) perbedaan dan persamaan antara ketentuan praktik jual beli hak cipta dalam hukum pidana Islam dan Undang-Undang Nomor 28 Tahun 2014 tentang Hak Cipta.

\section{Metode Penelitian}

Penelitian hukum yang diurai dalam penelitian ini merupakan jenis penelitian kualitatif yakni dimulai dengan asumsi dan penggunaan kerangka penafsiran atau teoritis yang membentuk atau mempengaruhi studi tentang permasalahan riset yang terkait dengan makna yang dikenakan oleh individu atau kelompok pada suatu permasalahan sosial atau manusia. ${ }^{10}$ Dengan kata lain penelitian ini berusaha mempelajari benda-benda di lingkungan alamiahnya serta berusaha untuk memaknai atau menafsirkan fenomena dalam sudut pandang makna-makna yang diberikan oleh masyarakat. Metode penelitian hukum dalam penelitian ini adalah metode penelitian hukum normatif atau yang seringkali disebut dengan penelitian hukum doktrinal.

Cakupan dalam metode hukum normatif terdiri dari penelitian terhadap asas-asas hukum, penelitian terhadap sistematika hukum, penelitian terhadap taraf sinkronisasi hukum, penelitian sejarah hukum, dan penelitian perbandingan hukum. ${ }^{11}$ Dengan konsep penelitian yang menyandarkan pada konsep metode penelitian yuridis normatif yang bersifat kualitatif, penelitian ini akhirnya diulas dengan mengacu pada norma hukum yang terdapat dalam peraturan perundang-undangan dan putusan pengadilan serta norma-norma hidup dan berkembang dalam masyarakat. Dalam penelitianinipendekatanpenelitian hokum normatif

${ }^{10}$ John W Crewell. Penelitian Kualitatif \& Desain Riset. Yogyakarta: Pustaka Belajar. 2015 hlm 58.

${ }^{11}$ Ibid. hlm 22. 
yang digunakanadalahpendekatan undang-undang (statuteapproach) dan pendekatan komparatif (comparativeapproach).

\section{Pembahasan}

1. Hak Cipta dalam Hukum Islam

Islam terhadap salah satu anugerah istimewa yang Allah berikan terhadap manusia berupa akal, melahirkan sebuah konsep hak yang melekat pada diri seseorang untuk mengakui serta melestarikan buah karyanya. Dalam literatur Islam kontemporer, hak tersebut biasa dikenal dengan istilah حق الابتكر (haq al ibtikar) yang memiliki arti hak cipta. Dalam ruang lingkup haq al ibtikar, secara etimologi lafadz حق (haq) memiliki arti sebagai kewenangan atau kepemilikan atas suatu karya cipta yang baru diciptakan sedangkan ابتكار (ibtikar) yang merupakan kata kerja yang lampau (fi'il madhi) memiliki arti menciptakan. ${ }^{12}$ Maka jika dikatakan bahwa ابتكر الثيء (ibtika raalsyai'a), itu artinya “ia telah menciptakan sesuatu". ${ }^{13}$ Secara terminologi, haq al ibtikaratau hak cipta ini memiliki arti sebagai "hak istimewa atas suatu ciptaan yang pertama kali diciptakan".14 Definisi secara terminologi tersebut diambil atas dasar arti kata lafadz ابتكار" (ibtikara) itu saling berdekatan. Beberapa referensi menunjukkan bahwa lafadz tersebut memiliki arti pagi-pagi, cepat-cepat, atau segera.

Dalam undang-undang hukum positif di Indonesia, pengertian bahkan konsep haq al ibtikar (hak cipta) telah lama dikenal, pengaturan tentangnya sudah ada dan diberlakukan sejak zaman Hindia Belanda dengan berlakunya Auteureswet 1912. Pada undang-undang terbaru yang digunakan hingga saat ini, pengertian hak cipta tercantum pada Pasal 1 ayat (1) Undang-Undang Nomor 28 Tahun 2014 tentang hak cipta yang

\footnotetext{
${ }^{12}$ Agus Suryana. Al Mashlahah Jurnal Hukum dan Pranata Sosial Islam Hak Cipta Perspektif Hukum Islam, hlm 249.

${ }^{13}$ AW Munawwir. Kamus Al Munawwir Indonesia-Arab Terlengkap. Surabaya: Pustaka Progressif. 2007, hlm101.

${ }^{14}$ Agus Suryana, Op. Cit. hlm 250
} 
menjelaskan bahwa "hak cipta adalah hak eksklusif pencipta yang timbul secara otomatis berdasarkan prinsip deklaratif setelah suatu ciptaan diwujudkan dalam bentuk nyata tanpa mengurangi pembatasan sesuai dengan ketentuan peraturan perundang-undangan". ${ }^{15}$ Hak eksklusif yang dimaksud merupakan hak yang semata-mata diperuntukkan bagi pemegangnya sehingga tidak ada pihak lain yang diperbolehkan memanfaatkan hak tersebut tanpa izin dari pencipta atau pemegangnya. ${ }^{16}$

Definisi serupa juga diungkapkan oleh Majelis Ulama Indonesia (MUI) dalam fatwanya yakni hak cipta merupakan hak eksklusif bagi pencipta atau penerima hak untuk mengumumkan atau memperbanyak ciptaannya atau memberi izin untuk itu dengan tidak mengurangi pembatasan-pembatasan menurut peraturan perundang-undangan yang berlaku. ${ }^{17}$ Dari kedua definisi tersebut, tidak tampak adanya perbedaan mencolok yang kemudian menjadikan definisi hak cipta memerlukan penafsiran lebih lanjut, terlebih dengan adanya hak eksklusif yang disebutsebut sebagai hak melekat dari sebuah karya cipta yang baru diciptakan. Keserupaan pandangan tentang definisi hak cipta ini juga tidak sedikit disepakati oleh para cendekiawan muslim.

Namun begitu, dari sekian banyak literatur yang beredar di kalangan para cendekiawan tersebut, sebagian besar arah pembahasannya tertuju kepada hak cipta atas karya tulis (haq atta'lif). Di antaranya adalah yang diungkapkan oleh Sa'duddin bin Muhammad Al Kibi, seorang cendekiawan muslim yang menyatakan bahwa definisi haq alta'lif adalah:

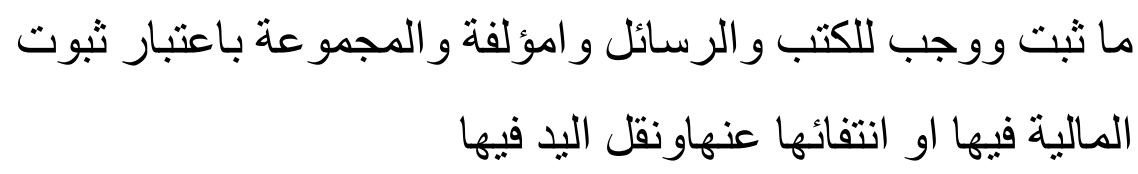

"Sesuatu (hak) yang telah tetap dan ada pada buku, makalah, karangan dan bunga rampai yang dianggap sebagai hak kebendaan padanya, serta

\footnotetext{
${ }^{15}$ Undang-Undang Nomor 28 Tahun 2014 tentang Hak Cipta, hlm 3

${ }^{16}$ AminWazan. Pelanggaran Hak Cipta: Studi Komparatif Undang-Undang No. 19Tahun 2014 Tentang Hak Cipta dan Hukum Islam. 2009, hlm13

${ }^{17}$ Agus Suryana, Op. cit. hlm 251
} 
hak untuk menyalinnya"18 dalam konteks hak kebendaan yang disebutkan dalam definisi diatas adalah bahwa hak ini dianggap sebagai hak suatu harta, sedangkan hak untuk menyalin merupakan hak untuk memperbanyak karya tulis. Keseluruhan klarifikasi hak diatas menjadi milik bagi setuap pengarang atau penulis sebagai pembuat dari karya tulisnya."

Dalam kaitannya dengan Hak Kekayaan Intelektual (HKI), hak cipta muncul sebagai bagian yang tak terpisahkan darinya yang bergerak di bidang seni, sastra dan ilmu pengetahuan. ${ }^{19}$ Keberadaan hak cipta ini kemudian dimaksudkan untuk memberikan motivasi serta mendorong kreativitas pencipta yang nantinya diharapkan akan memaksimalkan pencapaian target pertumbuhan ekonomi yang berbasis pada ruang lingkup seni, sastra dan ilmu pengetahuan. Islam pun dengan prinsip kuat dalam menghormti hak setiap individu, ingin mendorong siapa saja untuk bekerja semaksimal mungkin dan mengharapkan hasil dari jerih payahnya. Kemudian daripada itu, diniscayakan akan timbul rasa menghormati antar sesama atas hasil jerih payah orang lain sebagaimana salah satu tujuan syariat Islam yaitu hifdhual mal (menjaga harta). Oleh karena hal tersebut, keberadaan kepemilikan hak cipta disebut sebagai ekspektasi dari pengakuan konsep harta dalam Islam.

Pengakuan konsep harta yang menyebabkan jatuhnya hak kepemilikan semacam ini dalam Islam merupakan kecenderungan dan naluri alamiah serta hak individu yang diakui oleh syari'at serta dilindungi oleh agama-agama samawi lainnya. ${ }^{20} \mathrm{Al}$ Qur'an surat Ali Imran ayat 14 berbunyi:

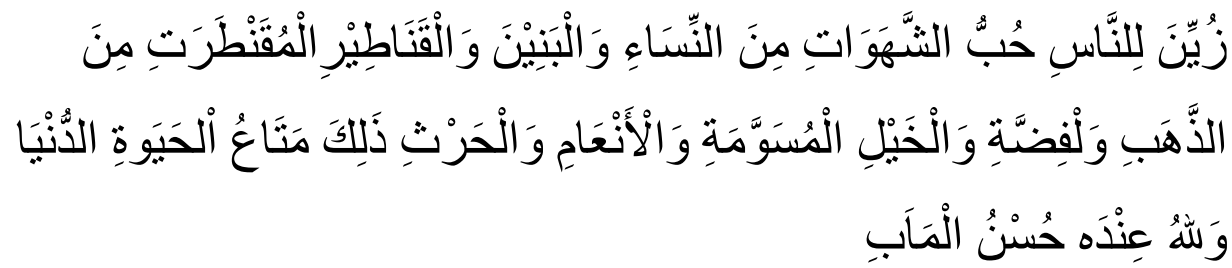

${ }^{18}$ Ibid.

${ }^{19}$ Arif Lutviansori, Loc.cit.

${ }^{20}$ WahbahAz Zuhaili. Op.cit.hlm33 
"Dijadikan indah pada (pandangan) manusia kecintaan kepada apa-apa yang diingini, yaitu: wanita-wanita, anak-anak, harta yang banyak dari jenis emas, perak, kuda pilihan, binatang-binatang ternak dan sawah ladang. Itulah kesenangan hidup di dunia, dan di sisi Allahlah tempat kembali yang baik (syurga)". ${ }^{21}$

Didasari pula oleh hadist Nabi Muhammad SAW dari Anas bin Malik ra yaitu:

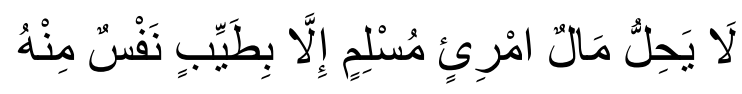

"Tidak halal harta seorang Muslim (bagi seorang Muslim yang lain) kecuali dengan kerelaan hatinya" (HR ad-Daraquthni) ${ }^{22}$

Sampai di sini bisa dipahami bahwa penyamaan antara konsep harta dan hak cipta berikutnya melahirkan pernyataan bahwa sejauh ini hak cipta dalam Islam dipandang sebagai hak kekayaan yang harus mendapatkan perlindungan hukum sebagaimana perlindungan hukum terhadap hak milik seseorang. Bahkan, pelanggaran terhadapnya sudah memasuki domain halal dan haram. Halal dalam arti sah untuk dilakukan, sedangkan haram adalah sebaliknya, yakni dilarang keras untuk dilakukan. Oleh sebab itulah kepada pelanggarnya dikatakan telah berbuat dosa dan mendapat siksa kelak di akhirat. ${ }^{23}$

Beberapa teori terkait konsep hak cipta berikut pelanggarannya tersebut dewasa ini dirasa masih belum cukup mewadahi dinamika perkembangan teknologi dan informasi yang banyak melahirkan produkproduk modernitas baru yang memerlukan kajian lebih komprehensif untuk menjawab legalitasnya. Seperti halnya acara yang baru-baru ini diselenggarakan oleh Internatioal BookFair (IIBF) yang diberitakan dengan tema "IIBF sukses gelar jual beli hak cipta antara penerbit Indonesia dan

${ }^{21}$ Departemen Agama RI. Op.cit. Hlm 77

${ }^{22}$ Wahbah Az Zuhaili. Op.cit. hlm 34

${ }^{23}$ Nur Sania. Hak Cipta di Era Modern (Perspektif Hukum Islam Dalam Menyelesaikan Persoalan Kontemporer). hlm 72 
asing" pada September 2017 lalu.24 Dalam wawancara yang dilakukan oleh pihak Republika terhadap ketua panitia penyelenggara acara tersebut diketahui bahwa acara tersebut diikuti oleh hampir 80 penerbit dan sudah diselenggarakan sejak tiga tahun yang lalu (terhitung dari tahun 2016). Jumlah tersebut diprediksikan akan meningkat setiap tahunnya sesuai dengan prediksi awal yang hanya ditargetkan sebanyak 50 peserta. Hak cipta yang berhasil dijual pun dinyatakan tidak sedikit, salah satunya adalah penerbit Kesai Blanc asal Indonesia yang berhasil menjual sembilan hak cipta terhadap penerbit Sourten Publishing Media dan tujuh ke Sinolingua Cina.

Menyikapi keberadaan acara tersebut, dengan transaksi yang sebenarnya cukup asing di telinga penulis, kiranya beberapa pertanyaan terkait hukum legalitasnya dalam Islam perlu dikupas secara tuntas. Sebab dalam perspektif hukum positif, transaksi semacam ini mampu dijawab dengan keberadaan Pasal 8 Undang-Undang Nomor 28 Tahun 2014 yakni tentang implementasi keberadaan hak ekonomi dalam hak cipta. ${ }^{25}$ Namun dalam Islam, sesuai dengan pengetahuan awal bahwa konsep hak cipta ini memang masih tergolong baru, maka untuk menjawabnya juga memerlukan analogi kuat sesuai dengan konsep kepemilikan yang disetarakan dengannya.

Jual beli pada umumnya merupakan sebuah transaksi yang landasannya nyaris sempurna dari beberapa sumber hukum Islam. Al Qur'an, hadist, dan ijma' para ulama juga tidak saling bertentangan satu sama lain terkait kebolehannya. Namun begitu, analogi tersebut belum sepenuhnya bisa menjawab pertanyaan yang ada oleh karena salah satu struktur dalam jual beli tersebut berbeda dengan jual beli pada umumnya. Disebutkan bahwa struktur jual beli ada empat, yaitu: 'aqidain (penjual dan pembeli); ma'qud 'alaih (mabi' dan tsaman) dan shighah (ijab dan qabul). ${ }^{26}$ Dari ketiga struktur transaksi jual beli tersebut, satu di antaranya merupakan

${ }^{24}$ Andi Nur Aminah. IIBF 2016 Sukses Gelar Bisnis Jual Beli Hak Cipta.http://m.republika.co.id/berita/nasional/umum/16/10/01/oec8n4384-iibf-2016-suksesgelar-bisnis-jual-beli-hak-cipta. diakses tanggal 26 November 2018.

${ }^{25}$ Undang-Undang Nomor 28 Tahun 2014 Tentang Hak Cipta. hlm 9 hlm 3.

${ }^{26}$ Tim Laskar Pelangi. Metodologi Fiqh Mu'amalah. Lirboyo: LirboyoPress. 2013, 
letak titik perbedaan antara jual beli hak cipta dan jual beli pada umumnya. Dalam hal ini perbedaannya terdapat dalam ma'qud 'alaih atau dengan kata lain adalah obyek dari akad jual beli. Secara lebih spesifik, dari dua unsur yang terdapat dalam struktur ma'qud 'alaih (barang dan pembayaran) yang lebih dititikberatkan dalam menjawab hal ini adalah dari segi barang (mutsman). Dalam hal ini, kriteria barang yang mampu mencapai syarat untuk diperjualkan ada lima. ${ }^{27}$

a. Mutaqawwim atau mutamawwal (barang yang memiliki nilai intrinsik yang dapat terpengaruh oleh fluktuasi harga)

b. Muntafa' bih (barang yang memiliki nilai kemanfaatan.)

c. Maqdur'ala taslim (barang yang mampu diserah terimakan.)

d. Li al 'aqid wilayah (pelaku transaksi harus memiliki otoritas kewenangan atas ma'qud 'alaih baik barang maupun pembayarannya)

e. Ma'lum (keberadaan ma'qud 'alaih harus diketahui secara transparan)

Dari penjelasan tersebut ditemukan bahwa letak perbedaan antara jual beli hak cipta dan jual beli pada umumnya tidak cukup signifikan. Hampir seluruh struktur serta unsur jual beli terdapat pada jual beli hak cipta. Hanya saja dalam menyetarakan ma'qud 'alaih terhadap jenis harta semacam hak cipta, diperlukan pemahaman lebih lanjut tentang bagaimana menjatuhkan konsep kemanfaatan (muntafa' bih) dalam hak cipta yang menjadi salah satu kriteria suatu barang yang layak diperjualbelikan. Dan pada akhirnya penulis menyimpulkan bahwa kemanfaatan hak cipta dapat dimiliki baik dalam perspektif syar'i maupun 'urf. Dengan kata lain, legalitas jual beli hak cipta dapat dicapai dalam Islam sebagaimana Islam melegalkan praktek jual beli pada umumnya.

\section{Hak Cipta dalam Hukum Positif}

Langkah Dewan Perwakilan Rakyat Republik Indonesia (DPR RI) dan Pemerintah mengganti Undang-Undang Nomor 19 Tahun 2002 tentang Hak Cipta dengan Undang-Undang Nomor 28 Tahun 2014 ini merupakan bukti dari kesungguhan upaya negara untuk melindungi hak ekonomi dan hak moral pencipta dan pemilik hak terkait sebagai unsur

${ }^{27}$ Wahbah Az Zuhaili. Op.cit. Jilid 5, hlm 59. 
penting dalam pembangunan kreativitas nasional. Karena dengan teringkarinya hak ekonomi dan hak moral dapat mengikis motivasi para pencipta dan pemilik hak terkait untuk berkreasi. Hilangnya motivasi seperti ini akan berdampak luas pada runtuhnya kreativitas makro bangsa Indonesia. Bercermin kepada negara-negara maju dimana perlindungan yang memadai terhadap hak cipta merupakan komponen terbesar dalam mewujudkan pertumbuhan ekonomi kreatif secara signifikan dan dalam implementasinya memberikan kontribusi nyata bagi perekonomian dan kesejahteraan rakyat. ${ }^{28}$

Pernyataan yang muncul dari keberadaan ratio legis Undang-Undang Nomor 28 Tahun 2014 tersebut adalah bahwa Indonesia merupakan negara yang sangat memperhatikan nilai-nilai hak milik yang melekat pada diri setiap individu. Di antaranya adalah adanya hak eksklusif yang melekat pada diri pencipta atas karya cipta sebagaimana dalam penjelasan sebelumnya. Munculnya hak eksklusif pada diri seorang pencipta yaitu setelah sebuah karya cipta diwujudkan, dan pelaksanaannya juga bermula sejak saat itu. ${ }^{29}$ Oleh karenanya pula, tidak ada yang diperbolehkan untuk memanfaatkan hak cipta tersebut kecuali atas izin pemilik atau pemegangnya. Hal ini dilatarbelakangi oleh pemikiran bahwa untuk menuangkan ide serta gagasan dalam sebuah media karya cipta bukanlah hal yang mudah untuk dilakukan. Keberadaan hak eksklusif sebagai kekuasaan pribadi atas karya cipta yang bersangkutan merupakan hak yang melekat erat kepada pemiliknya. Dalam konteks hak eksklusif ini, hak terkait yang juga turut melekat ada dua, yaitu hak ekonomi dan moral.

Hak ekonomi sebagaimana yang tercantum dalam Pasal 8 UndangUndang Nomor 28 Tahun 2014 didefinisikan sebagai hak eksklusif pencipta atau pemegang hak cipta untuk mendapatkan manfaat ekonomis atas ciptaan. ${ }^{30}$ Hak inilah yang kemudian dijadikan dasar kebolehan seorang pencipta mengambil royalti tas karya ciptanya. Dengan begitu pula, keberadaan transaksi jual beli hak cipta didasarkan pada keberadaan hak ekonomi ini. Sedangkan hak moral merupakan hak yang tidak dapat

\footnotetext{
${ }^{28}$ Ibid.

${ }^{29}$ Gatot Supramono. Op.cit. hlm 44

${ }^{30}$ Undang-Undang Hak Cipta. hlm 9
} 
diganggu gugat oleh siapapun dan senantiasa melekat pada diri penciptanya dimanapun hak cipta tersebut berada dan sampai kapanpun bahkan meski pnciptanya telah meninggal dunia.

3. Persamaan dan Perbedaan Ketentuan Hukum Transaksi Jual Beli Hak Cipta Dalam Perspektif Hukum Pidana Islam dan Undang-Undang Nomor 28 Tahun 2014 tentang Hak Cipta

Pada hakikatnya, titik persamaan dan perbedaan dari ketentuan hukum pidana Islam dan Undang-Undang Nomor 28 Tahun 2014 tentang Hak Cipta mengenai legalitas transaksi jual beli hak cipta tidak begitu dinilai signifikan. Hanya saja penempatan analogi antara keduanya berada pada konsep yang berbeda secara istilah. Selanjutnya perbedaan dan persamaan tersebut peneliti deskripsikan dalam sebuah tabel berikut.

\begin{tabular}{|c|c|}
\hline Hukum Pidana Islam & $\begin{array}{c}\text { Undang-Undang Nomor } 28 \text { Tahun } \\
2014 \text { Tentang Hak Cipta }\end{array}$ \\
\hline $\begin{array}{l}\text { - Analogi kepemilikan hak cipta } \\
\text { terhadap kepemilikan harta } \\
\text { - Perlindungan terhadap hak } \\
\text { cipta sebagaimana } \\
\text { perlindungan terhadap harta } \\
\text { - Legalitas jual beli hak cipta } \\
\text { diakui melalui legalitas jual beli } \\
\text { pada umumnya } \\
\text { - Didasarkan pada perspektif 'urf } \\
\text { dalam kriteria muntafa' bih pada } \\
\text { mauqud 'alaih yang menyatakan } \\
\text { bahwa hak cipta bersifat } \\
\text { maqshuudan 'urfan yakni diakui } \\
\text { secara publik memiliki nilai } \\
\text { ekonomis dan layak } \\
\text { diperjualbelikan. }\end{array}$ & $\begin{array}{l}\text { - Hak eksklusif sebagai hak } \\
\text { melekat atas kepemilikan hak } \\
\text { cipta } \\
\text { - Keberadaan hak ekonomi } \\
\text { sebagai dasar penerapan dari } \\
\text { hak eksklusif } \\
\text { - Implementasi hak ekonomi } \\
\text { tehadap royalti yang } \\
\text { didapatkan oleh pencipta atas } \\
\text { kemanfaatan yang diambil } \\
\text { darinya } \\
\text { - Legalitas jual beli hak cipta } \\
\text { dilandaskan pada transaksi- } \\
\text { transaksi legal lainnya yang } \\
\text { tercantum dalam Pasal } 9 \text { ayat } \\
\text { (1) Undang-Undang Nomor } 28 \\
\text { Tahun } 2014 \text { tentang Hak Cipta }\end{array}$ \\
\hline
\end{tabular}


Secara sederhana, perbedaan dan persamaan antara perspektif hukum pidana Islam dan Undang-Undang Nomor 28 Tahun 204 tentang hak cipta terkait legalitas jual beli hak cipta sudah cukup menjawab dengan adanya substansi tabel di atas. Namun secara lebih lanjut, analisis tentang legalitas jual beli hak cipta penulis uraikan secara deskriptif dalam penjabaran berikut.

a. Analogi Sifat Hak Cipta

Meski secara istilah masih tergolong baru dan tidak ditemukan dalam nash utama, eksistensi hak cipta dalam hukum pidana Islam sudah diakui jauh sebelum istilah tersebut dikenal secara nyata. Dalam penganalogiannya, akhirnya ditemukan hak cipta dapat dikaji status hukumnya melalui sifat-sifatnya yang tidak berbeda dengan harta. Dalam hal ini, akhirnya membawa sebuah pemahaman bahwa untuk mengenal hak cipta, sama dengan mengenal konsep harta. Dalam Islam, pernyataan tentang konsep harta terdapat dalam Al Qur'an surat Al Hadiid ayat 7:

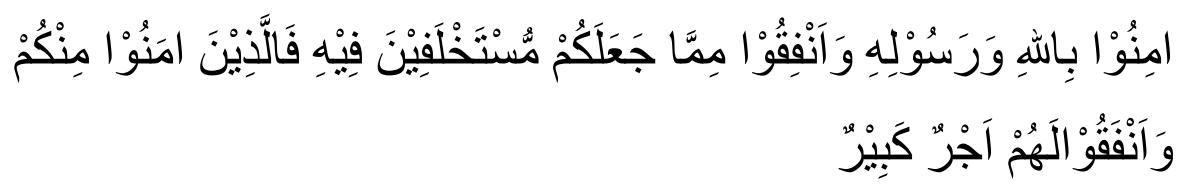

"Berimanlah kamu kepada Allah dan Rasul-Nya dan nafkahkanlah sebagian dari hartamu yang Allah telah menjadikan kamu menguasainya. Maka orang-orang yang beriman di antara kamu dan menafkahkan (sebagian)dari hartanya memperoleh pahala yang besar". ${ }^{31}$

Sedangkan sifat hak cipta dalam hukum positif dianalogikan terhadap hak kebendaan, sebagaimana yang dinyatakan dalam Pasal 16 ayat (1) yaitu bahwa "hak cipta merupakan benda bergerak yang tidak berwujud". ${ }^{32}$

b. Konsep Kepemilikan

Hak cipta dalam perspektif hukum pidana Islam dan hukum positif di Indonesia sama melahirkan konsep kepemilikan, perbedaannya hanya terdapat dalam penyebutannya. Dalam hukum Islam konsep kepemilikan

\footnotetext{
${ }^{31}$ Departemen Agama RI. Op.cit. hlm 901

${ }^{32}$ Undang-Undang Nomor 28 Tahun 2014 Tentang Hak Cipta. hlm 12
} 
hak cipta berada dalam haqq al milkiyah (hak milik) yang berarti hubungan keterikatan antara seseorang dengan harta yang dikukuhkan dan dilegitimasi keabsahannya oleh syara'. ${ }^{33}$ Sedangkan dalam hukum positif di Inonesia melahirkan hak berupa hak eksklusif. Hal ini dilandasi atas dasar Pasal 1 Undang-Undang Nomor 28 Tahun 2014 tentang Hak Cipta yang menyatakan bahwa "hak cipta adalah hak eksklusif pencipta yanng timbul secara otomatis berdasarkan prinsip deklaratif setelah suatu ciptaan diwujudkan dalam bentuk nyata tanpa mengurangi pembatasan sesuai dengan ketentuan peraturan perundang-undangan". ${ }^{34}$

c. Batasan Perlindungan Hak Cipta

Hak cipta dengan segala kemanfaatan yang dibawa, mendapat perlindungan optimal baik dalam konteks hukum pidana Islam maupun hukum positif. Dalam hukum pidana Islam, perlindungan terhadap hak tersebut dibatasi dengan identifikasi kasus terkait jenis pelanggaran yang dilakukan terhadapnya. Karena kepemilikannya dianalogikan dengan kepemilikan harta. Hal serupa juga dinyatakan dalam hukum positif di Indonesia melalui dari Undang-Undang hak Cipta Pasal 26 tentang pembatasan perlindungan hak cipta yaitu:

1) Penggunaan kutipan singkat ciptaan dan/ atau produk hak terkait untuk pelaporan peristiwa aktual yang ditujukan hanya untuk keperluan penyediaan informasi aktual;

2) Penggandaan ciptaan dan/atau produk hak terkait hanya untuk kepentingan penelitian ilmu pengetahuan;

3) Penggandaan ciptaan dan/atau produk hak terkait hanya untuk keperluan pengajaran, kecuali pertunjukan dan fonogram yang telah dilakukan pengumuman sebagai bahan ajar dan

4) Penggunaan untuk kepentingan pendidikan dan pengembangan ilmu pengetahuan yang memungkinkan suatu ciptaan dan/atau produk hak terkait dapat digunakan tanpa izin pelaku pertunjukan produerfonogram, atau lembaga penyiaran. ${ }^{35}$

d. Analisis hukum terhadap legalitas transaksi jual beli hak cipta

\footnotetext{
${ }^{33}$ Wahbahaz Az Zuhaili. Op.cit. hlm 449

${ }^{34}$ Undang-UndangNomor 28 Tahun 2014 Tentang Hak Cipta. Hlm 3

${ }^{35}$ Ibid.hlm 17
} 
Jual beli hak cipta dalam hukum pidana Islam merupakan jual beli yang tidak jauh berbeda dengan jual beli pada umumnya. Hanya saja, penganalogian salah satu struktur jual beli biasa dalam hal ini ma'qud 'alaih perlu lebih diperinci jika dikaitkan dengan konteks jual beli hak cipta sebagaimana yang telah dipaparkan dalam pembahasan sebelumnya. Oleh karenanya, legalitas jual beli hak cipta juga mampu dicapai dengan setara. Karena al-Qur'an sebagai nash utama telah menyebutkan secara sarih tentang legalitas jual beli sebagaimana pada umumnya. Hal ini dibuktikan dengan keberadaan surat al Qur'an surat al Baqarah ayat 275 yang berbunyi:

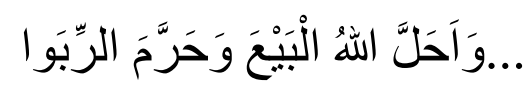

“...Dan Allah telah menghalalkan jual beli dan mengharamkan riba". ${ }^{36}$

Serupa pula dalam hukum positif di Indonesia, legalitas transaksi jual beli hak cipta sebenarnya sudah diketahui cukup lama. Hal ini terbukti dari praktik jual beli hak cipta yang ada dan diselenggarakan secara transparan. Karena dalam ketentuan hukum yang ada, terdapat dua hak terkait yang terlahir dari hak eksklusif yang dimiliki oleh pencipta, yakni hak ekonomi dan hak moral. Hak ekonomi inilah yang kemudian dijadikan landasan royalti sebagai keuntungan dari transaksi jual beli hak cipta. Beberapa transaksi serupa yang tercantum dalam Pasal 9 ayat (1) UndangUndang Nomor 28 tentang Hak Cipta juga turut menjadi landasan hukum atas legalitasnya. Transaksi-transaksi tersebut meliputi penerbitan ciptaan, penggandaan ciptaan dalam segala bentuknya, penerjemahan, pengadaptasian, pengaransemenan, pentransformasian, pendistribusian, pertunjukan, pengumuman, komunikasi, dan penyewaan ciptaan. ${ }^{37}$

\section{Kesimpulan}

Dengan didasarkan pada dua sumber hukum utama dalam Islam (al Qur'an dan al Sunnah), legalitas jual beli hak cipta juga didasarkan

\footnotetext{
${ }^{36}$ Departemen Agama RI. Op.cit. hlm 69

${ }^{37}$ Undang-Undang Nomor 28 Tahun 2014 Tentang Hak Cipta. hlm 10
} 
terhadap persepsi 'urf yang berada dalam syarat kemanfaatan suatu barang (muntafa' bih) pada kriteria obyek (mauqud 'alaih) dalam jual beli pada umumnya yang menyatakan bahwa hak cipta bersifat maqsudan 'urfan atau dengan kata lain diakui publik memiliki nilai ekonomis dan layak diperjualbelikan.

Transaksi ini sebenarnya secara teoritis sudah dijawab oleh keberadaan Pasal 4 dalam Undang-Undang Nomor 28 Tahun 2014 yang menyebutkan bahwa keberadaan hak terkait (hak moral dan hak ekonomi) yang muncul sebagai refleksi atas hak eksklusif bagi pencipta merupakan dasar diperbolehkannya seorang pencipta mengambil keuntungan ekonomi terhadap karya ciptanya. Secara khusus, keberadaan hak ekonomi inilah yang menjadi dasar royalti tersebut. Dilanjutkan pula oleh Pasal 9 ayat (1) yang menyebutkan beberapa transaksi-transaksi serupa yang legalitasnya dijamin oleh undang-undang yang ada.

Dalam konteks ketentuan hukum pidana Islam dan Undang-Undang Nomor 28 tahun 2014 tentang Hak Cipta, analisis tentang legalitas transaksi jual beli hak cipta pada hakikatnya tidak jauh berbeda. Bahkan bisa dikatakan bahwa perbedaan tipis antara keduanya hanya terdapat dalam istilah yang dipakai berikut analogi yang digunakan. Hal ini disebabkan karena dalam penempatannya, konsep jual beli hak cipta memerlukan beberapa analogi yang perlu dikaji lebih dalam. Utamanya dalam perspektif Hukum Pidana Islam yang memang masih asing mengenal jenis transaki ini. Berbeda halnya dengan keberadaan transaksi jual beli hak cipta yang cukup lama dibahas secara komprehensif dalam Undang-Undang khusus tentang hak cipta dalam hal ini Undang-Undang Nomor 28 tahun 2014. 


\section{DAFTAR PUSTAKA}

\section{Buku:}

Az Zuhaili, Wahbah. 2011. Fiqih Islam Wa Adillatuhu Juz 1. Jakarta: Darul Fikir.

Crewell, John W . 2015. Penelitian Kualitatif EDesain Riset. Yogyakarta: Pustaka Belajar.

Departemen Agama RI. 1993. Al Qur'an dan Terjemahannya. Jakarta: Surya Cipta Aksara.

Lindsey, Tim dkk. 2011. Hak Kekayaan Intelektual, Suatu Pengantar. Bandung: Alumni.

Lutviansori, Arif. 2010. Hak Cipta dan Perlindungan Folkor di Indonesia. Yogyakarta: Graha Ilmu.

Munawwir, AW. 2007. Kamus Al Munawwir Indonesia-Arab Terlengkap. Surabaya: Pustaka Progressif

Supramono, Gatot. 2010. Hak Cipta dan Aspek-Aspek Hukumnya. Jakarta: Rineka Cipta.

Tim Laskar Pelangi. 2013. Metodologi Fiqh Mu'amalah. Lirboyo: Lirboyo Press.

Undang-Undang Nomor 28 Tahun 2014 tentang Hak Cipta.

\section{Jurnal :}


Amin Wazan. 2009. Pelanggaran Hak Cipta: Studi Komparatif Undang-Undang No. 19Tahun 2014 Tentang Hak Cipta dan Hukum Islam.

Nur Sania. Hak Cipta di Era Modern (Perspektif Hukum Islam dalam Menyelesaikan Persoalan Kontemporer)

Rochim Al Audah. Al Mashlahah Jurnal Hukum Dan Pranata Sosial Islam: Hak Cipta dan Perlindungan Hak Kekayaan Intelektual dalam Perspektif Hukum Islam dan Perundang-undangan.

Suryana, Agus. Al Mashlahah Jurnal Hukum Dan Pranata Sosial Islam Hak Cipta Perspektif Hukum Islam.

\section{Internet :}

Andi Nur Aminah. IIBF 2016 Sukses Gelar Bisnis Jual Beli Hak Cipta.http://m.republika.co.id/berita/nasional/umum/16/10/01 /oec8n4384-iibf-2016-sukses-gelar-bisnis-jual-beli-hak-cipta. diakses tanggal 26 November 2018. 